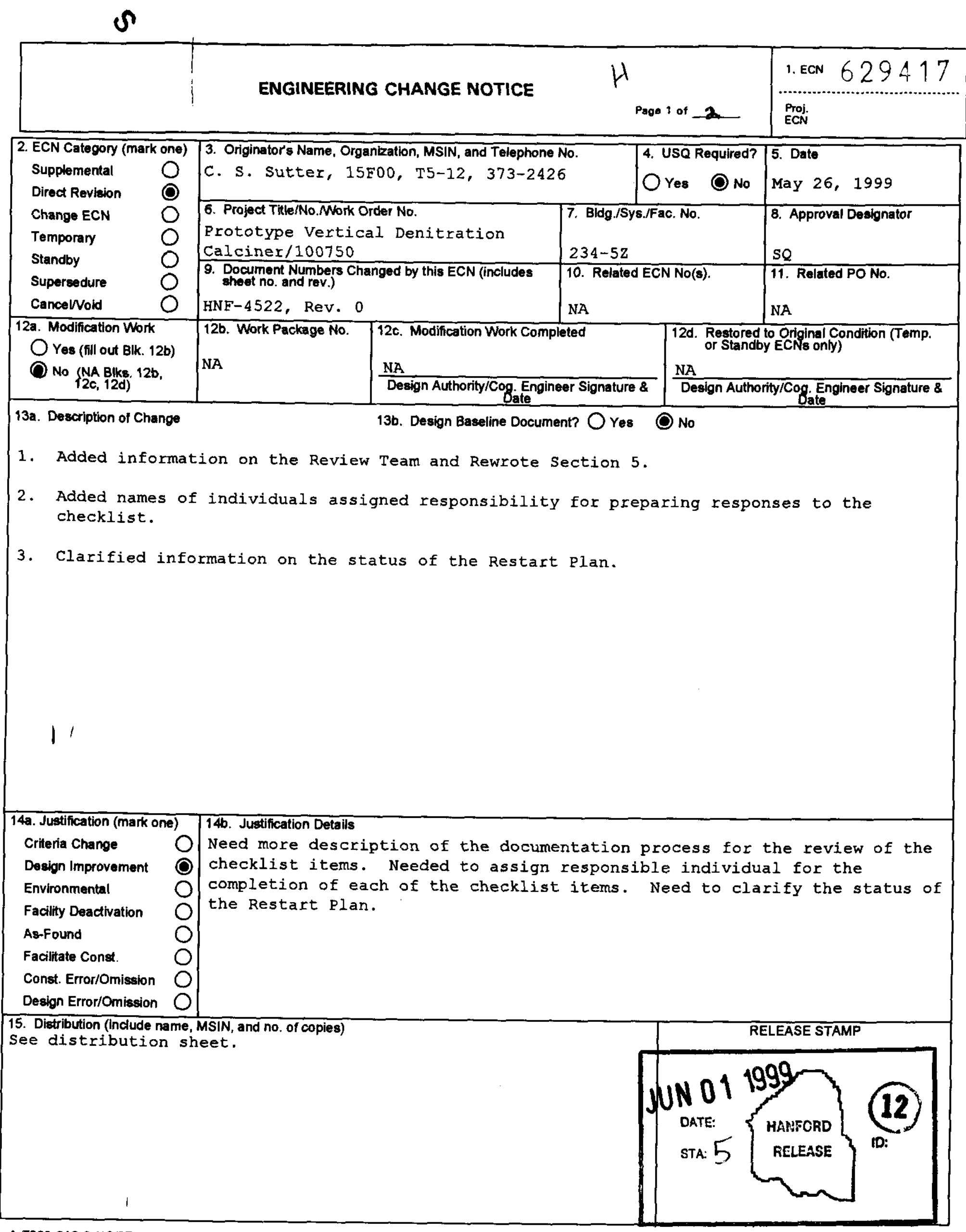




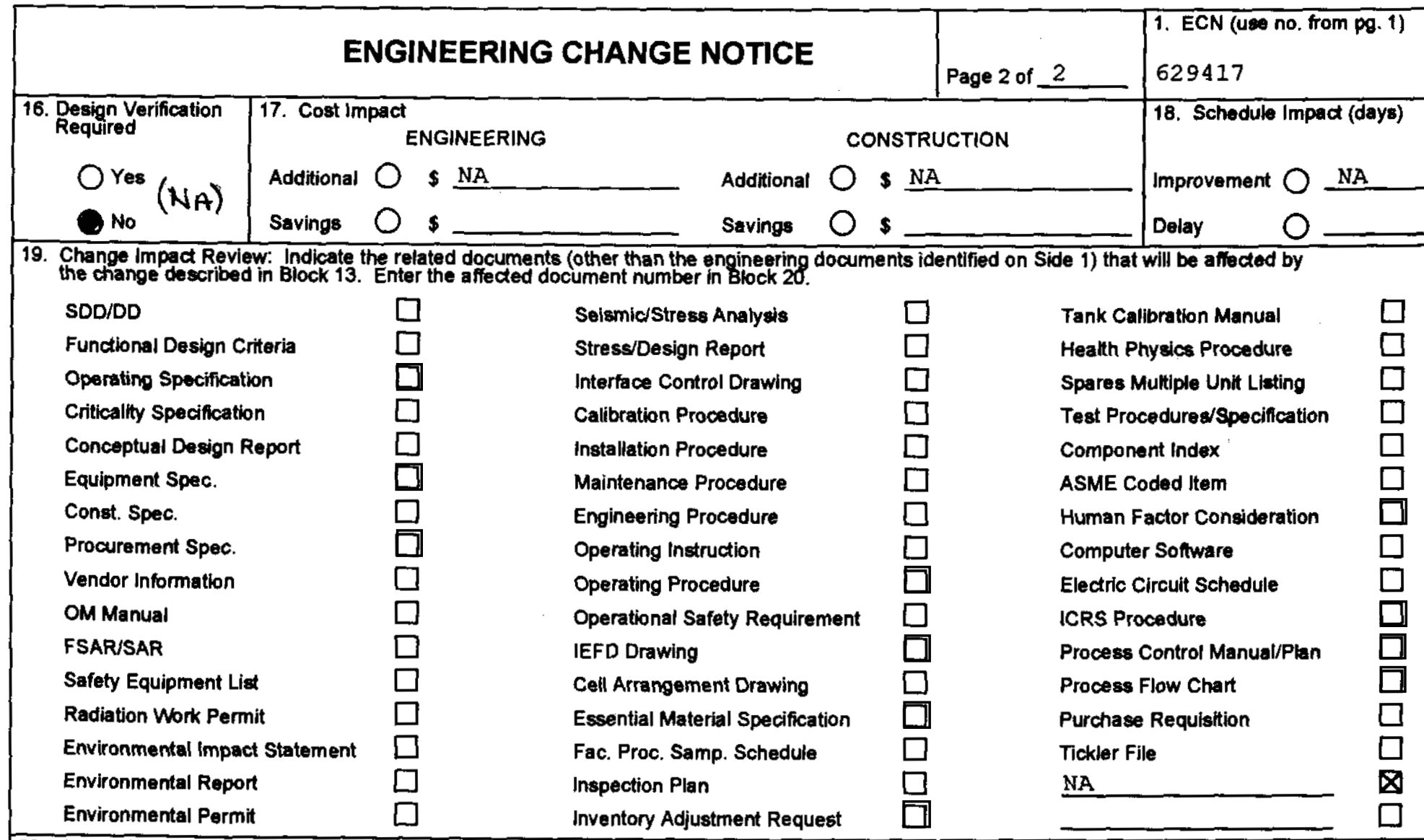

20. Other Affected Documents: (NOTE: Documents listed below will not be revised by this ECN.) Signatures below indicate that the signing organization has been notified of other affected documents listed below.

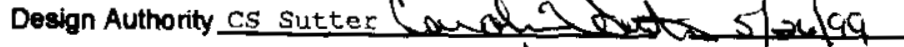

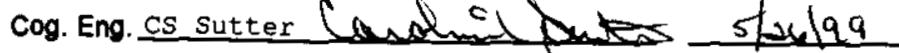
Cog. Mgr. CS Sutter QA $-$ ב_[_-
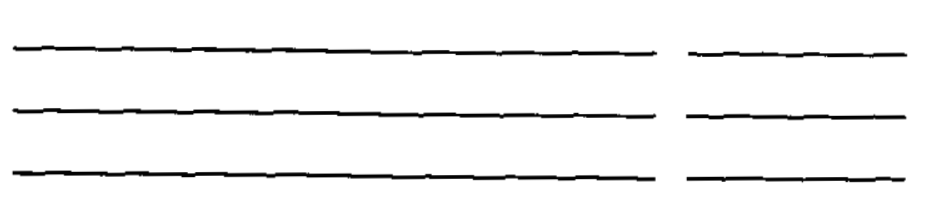

\section{DEPARTMENT OF ENERGY}

Signature or a Control Number that tracks the Approval Signature

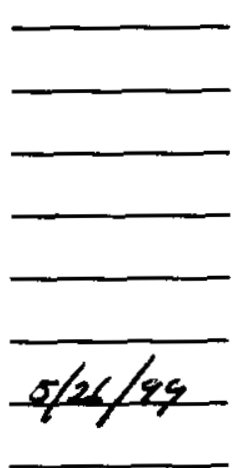

ADDITIONAL 


\title{
Activity Based Startup Plan for the Prototype Vertical Denitration Calciner
}

\section{S. Sutter}

P. O. Box 1200 MS T5-12

Richland, WA 99352

U.S. Department of Energy Contract DE-AC06-96RL13200

\author{
EDT/ECN: 629417 UC: \\ Org Code: 15F00 Charge Code: 100750 \\ B\&R Code: \\ Total Pages: 15
}

Key Words:

plutonium, plutonium nitrate, prototype calciner, restart, startup plan, direct denitration, vertical calciner, readiness

\section{Abstract:}

Testing activities on the Prototype Vertical Denitration Calciner at PFP were suspended in January 1997 due to the hold on fissile material handling in the facility. The restart of testing activities will require a review through an activity based startup process based upon Integrated Safety Management (ISM) principles to verify readiness. The Activity Based startup Plan has been developed for this process

TRADEMARK DISCLAIMER. Reference herein to any specific commercial product, process, or service by trade name, trademark, manufacturer, or otherwise, does not necessarily constitute or imply its endorsement, recommendation, or favoring by the United States Government or any agency thereof or its contractors or subcontractors.

Printed in the United States of America. To obtain copies of this document, contact: Document Control Services, P.O. Box 950, Mailstop H6-08, Richland WA 99352, Phone (509) 372-2420; Fax (509) 376-4989.
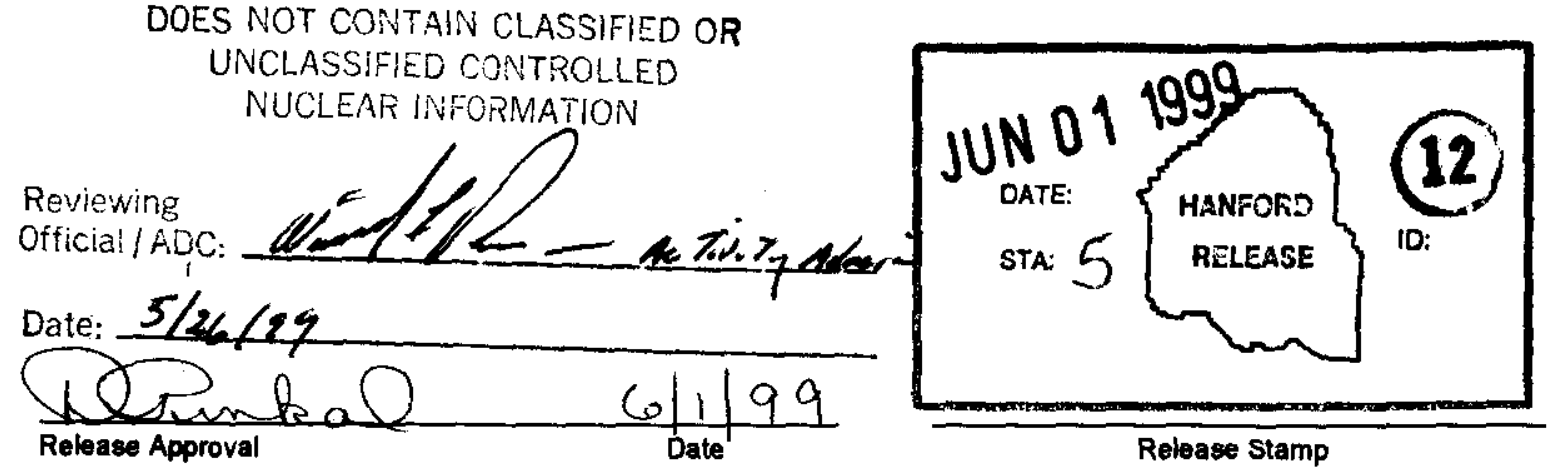

Release Stamp 


\section{RECORD OF REVISION}

(1) Document Number

HNF -4522

(2) Title

Activity Based startup Plan for the Prototype vertical Denitration Calciner

\section{Change Control Record}

(3) Revision
(4) Description of Change - Replace, Add, and Delete Pages

(7)

EDT 621551, May 18, 1999. Initial Issue

Added information on Review Team and rewrote Section 5. Added assignments to checklist.
Authorized for Release

\begin{tabular}{l|ll} 
(5) Cog. Engr. & (6) Cog. Mgr. Date
\end{tabular}

CS sutter CS sutter

Cs sutter CS sutter 5/26/99 andesuto and 9 ond

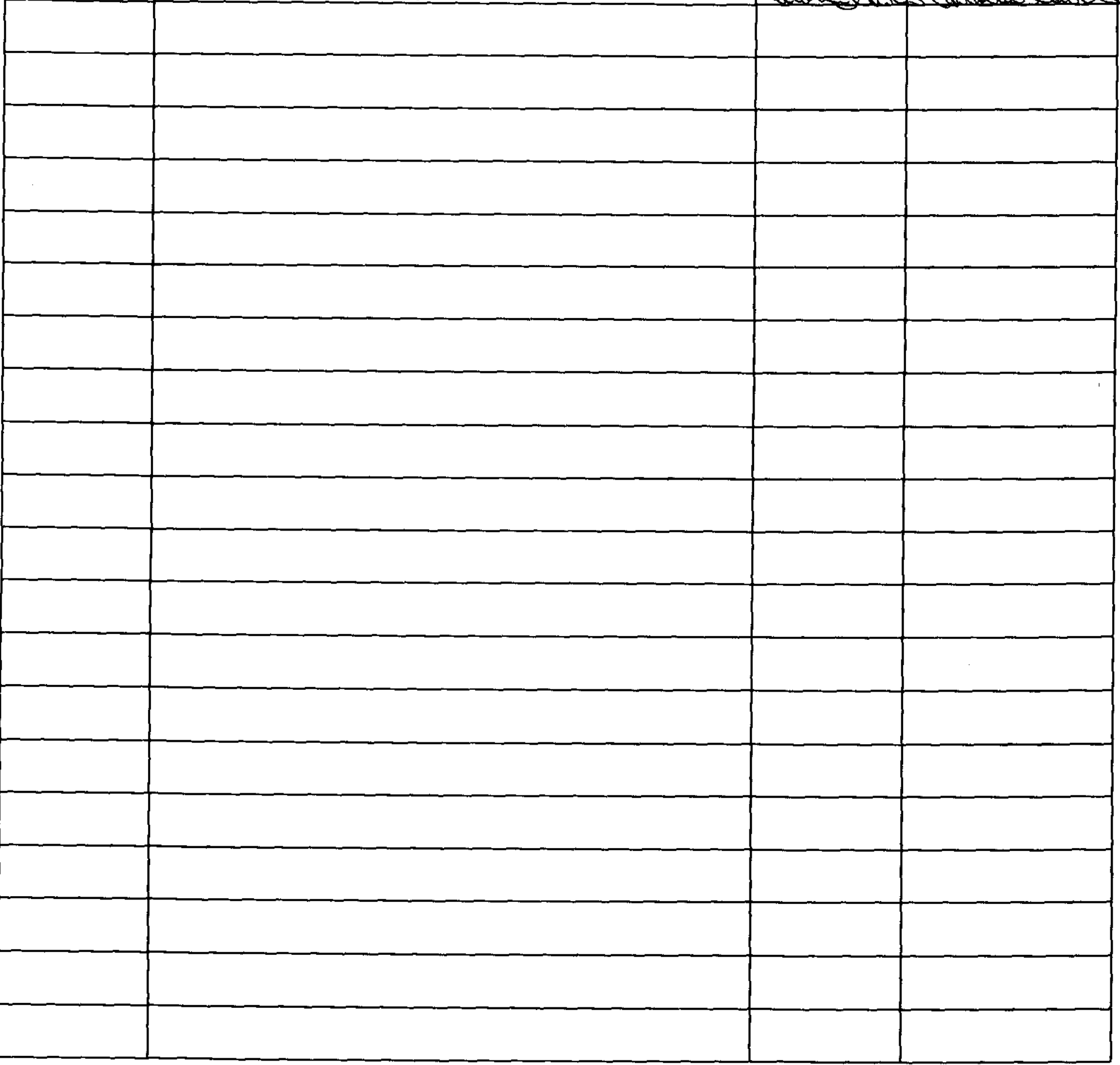




\section{HNF-4522}

\section{ACTIVITY BASED STARTUP PLAN FOR THE PROTOTYPE VERTICAL DENITRATION CALCINER}

May 26, 1999

Revision 1 
F. Coustord
Plutonium Finishing Plant Project C. S. Sutter, Manager, PPSL Plutonium Finishing Plant

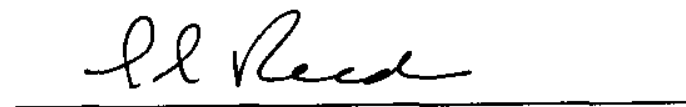

L. L. Reed, Manager, ESH\&QA Plutonium Finishing Plant
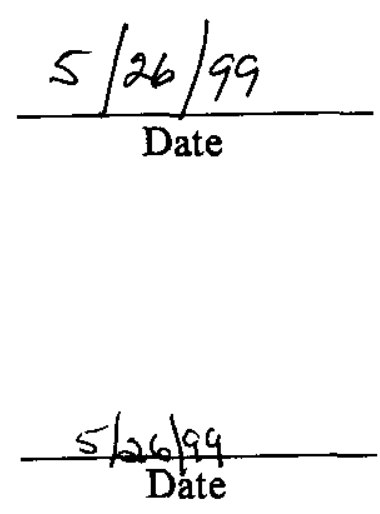

$$
\frac{5-26-99}{\text { Date }}
$$




\section{TABLE OF CONTENTS}

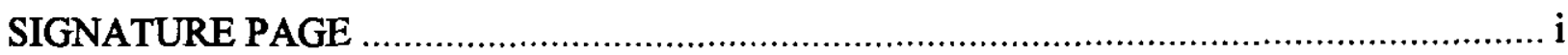

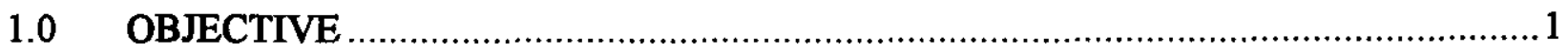

2.0 SCOPE OF THE RESTART OF PROTOTYPE VERTICAL DENITRATION

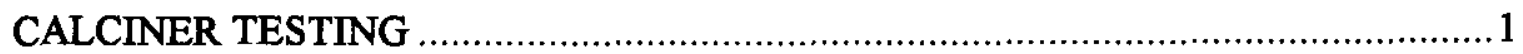

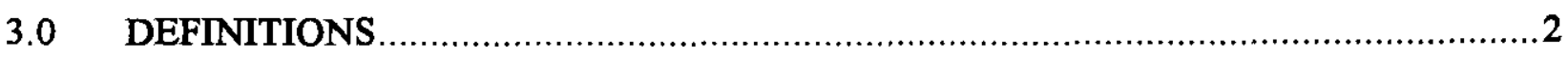

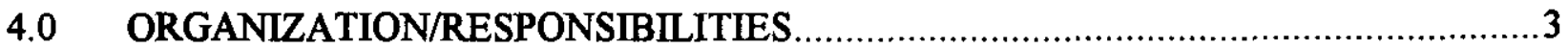

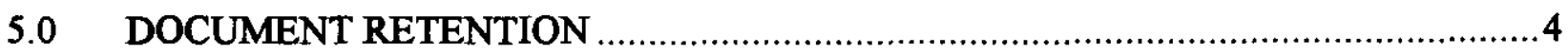

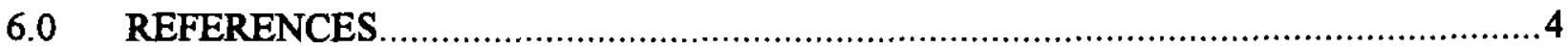

FIGURE 1 - Equipment Layout Prototype Vertical Denitration Calciner .................................5

ATTACHMENT A - Prototype Vertical Denitration Calciner Review Topic ...........................6 


\subsection{OBJECTIVE}

Testing activities on the Prototype Vertical Denitration Calciner (PVDC) at the Plutonium Finishing Plant (PFP) were suspended in January 1997 due to the hold on fissile material handling in the facility. The restart of activities associated with the testing will require a review through an activity based startup process based upon Integrated Safety Management (ISM) principles to verify readiness. This process is modeled after Attachment $\mathrm{C}$ of the Plan for the Resumption of Stabilization and Cleanout of the Plutonium Finishing Plant (Restart Plan), Reference 1, which governs the introduction of new feed types to the PFP furnaces. Document HNF-4522, Activity Based Startup Plan for the Prototype Vertical Denitration Calciner (Plan), has been developed for this readiness process with the objective of identifying those activities needed to guide and control preparations for the restart of the prototype calciner. The completion of the Plan provides a readiness determination basis to authorize safe resumption of PVDC testing activities. B\&W Hanford Company (BWHC) will execute the readiness process per this Plan with appropriate participation and oversight by Fluor Daniel Hanford (FDH) and the Department of Energy (DOE), Richland Operations Office (RL). This approach will further demonstrate that testing can be conducted in a manner that meets BWHC, FDH and DOE-RL expectations.

\subsection{SCOPE OF THE RESTART OF PROTOTYPE VERTICAL DENITRATION CALCINER TESTING}

Due to the nature of the fissile material handling hold in 1997, fissile material still resides in the PVDC. Equipment checkout and/or surrogate runs cannot be accomplished without disturbing the fissile material. To ensure that activities are accomplished safely, the Plan has been developed to verify readiness prior to initiating equipment checkout and surrogate (nitric acid) runs which are to be followed by test runs using plutonium bearing solutions. The performance of equipment checkout, surrogate runs and resumption of the testing program with plutonium bearing solutions will be governed by a restart plan. Authorization for restart of the prototype test program by the approval authorities, F. R. Crawford and A. Clark, is required to conduct the equipment checkout, surrogate runs and testing program after verification of readiness. Restart activities will be controlled by a Restart Plan, which is being developed.

Activities subject to the review include the testing activities associated with the PVDC located in Building 234-5Z, Room 188, Glovebox 188-1, and the direct supporting equipment located externally to the glovebox.

The Plan will evaluate the equipment, process, components, procedures and internal Plutonium |Process Support Laboratories (PPSL) support systems directly associated with the PVDC test program. The following identifies the equipment associated with the PVDC located in Glovebox 188-1: the vertical denitration calciner, scrubber, feed injection equipment, containers, tanks, 
ceramic filters, associated valves and metering pumps. External equipment includes the chiller system for the scrubber-chilled water, caustic supply and delivery pump, the control panel, process air system seismic isolation valves, and the seismic shutdown logic. See Figure 1 for a layout of the PVDC equipment.

Upon the completion of the review, the controlled restart of the PVDC will be conducted in I accordance with an approved Restart Plan, which is being developed. The Restart Plan will include a process to check out equipment, perform nitric acid testing operations; introduce plutonium bearing solutions, and achieving unrestricted testing. The Restart Plan will be modeled after Reference 1 and will be reviewed for adequacy as part of this review. The Restart Plan will include compensatory actions such as hold points and oversight to ensure safe operations until additional operating experience is achieved and unrestricted operations are authorized by the Senior Director of the PFP Project.

\subsection{DEFINITIONS}

Cognizant Engineer - The engineer designated by the PPSL Manager to be responsible for the development and conduct of the PVDC test program. The Cognizant Engineer is the subject matter expert for all calciner related topics and will complete Attachment $A$ in his areas of responsibilities.

PPSL Manager - The senior manager in charge of the PPSL and reports to the Senior Director, PFP Project. The PPSL Manager is the owner of the Plan. She is responsible for the execution, and configuration, control of the Plan.

Senior Director, PFP Project - The overall senior manager responsible for the operation of the PFP. The Senior Director will overview the conduct of the Plan, review the recommendations, and authorize the initiation of the Restart Plan.

Plutonium Process Support Laboratories (PPSL) - This organization conducts research and development activities to develop new process, refine process flow sheets and resolve operational problems. The PVDC test program is one such activity.

Test Plan - The documentation that governs the test program for the PVDC. The test plan for the PVDC test program is HNF-SD-CP-TP-088, "Test Plan for Radioactive Testing of the Vertical Direct Denitration Calciner " (Reference 2). The Test Plan includes items such as a description of the testing activities, expected results, safety, test procedure and oversight requirements.

Restart Plan - The restart plan governs the transition of the PVDC test program from the 
completion of the activity based startup review, through equipment checkout and surrogate runs, resumption of testing with plutonium bearing solution to unrestricted testing. The Restart Plan will be modeled after Reference 1 developed for Thermal Stabilization.

Review Team - The PVDC Activity Based Review Team is a team appointed by the Senior Director, Plutonium Finishing Plant Project that will review the documentation package for each line item in Attachment A. If the documentation is acceptable, the team leader will signoff the line item as complete.

\subsection{ORGANIZATION/RESPONSIBILITIES}

4.1 The functional organization responsible for the PVDC test program will be the PPSL.

4.2 Responsibilities are assigned as follows:

4.2.1 The Manager, PPSL shall be responsible under the Senior Director of PFP Project for the control of revisions to the Plan and execution of all activities in the Activity Based Startup Review Plan. This will include, but is not limited to, coordination with the cognizant engineer, Criticality Safety Representative, and Environmental, Safety, Health and Quality Manager to ensure that all process activities are completed in a timely, safe manner.

4.2.2 The Cognizant Engineer shall have the responsibility to complete Attachment A and execute the restart activities contained in the Startup Plan.

4.2.3 The PVDC Activity Based Review Team (Review Team) will have the responsibility to review the documentation prepared in response to Attachment A, to ensure it is adequate and documents readiness to restart the PVDC and made recommendations.

\subsection{Management Oversight}

4.3.1 The Manager, PPSL is the overall coordinator of the restart process. These responsibilities include the oversight of all activities associated with the execution of the Activity Based Startup Plan and the Restart Plan.

4.3.2 The Senior Director is responsible for appointing the Review Team and the authorization of the execution of the Restart Plan. 


\subsection{PPSL Support}

4.4.1 The responsibilities for PPSL support personnel shall be as directed by PFP procedures and test plans.

\subsection{DOCUMENT}

5.1 The PPSL Manager will assign individuals responsible for each line item on Attachment A. Each assigned individual will prepare documentation to address assigned items. The documentation must describe the scope, discuss the closure, and the verification performance, as required. After completion of the documentation, the assigned individual will submit the documentation to the PPSL Manager.

After the PPSL Manager has reviewed the documentation, the responsible individual will signoff the line items as complete. Copies of the documentation will then be submitted to the Review Team. The Review Team will review the documentation to ensure it adequately addressed the checklist item. The Review Team will then validate closure through a review of the documentation with field validation as required. If the documentation is acceptable, the Review Team lead will sign the line item off as complete.

At the completion of the checklist, the PPSL Manager will sign the checklist and gain Senior Director concurrence to initiate the Restart Plan. The PPSL Manager shall control all completed check sheets and supporting documents as quality documents in accordance with current procedures.

\subsection{REFERENCES}

6.0 Plan for the Resumption of Stabilization and Cleanout of the Plutonium Finishing Plant (Restart Plan), Revision 2, dated February 11, 1999.

6.1 HNF-SD-CP-TP-088, Test Plan for Radioactive Testing of the Vertical Direct Denitration Calciner. 
Figure 1 - Equipment Layout Prototype Vertical Denitration Calciner

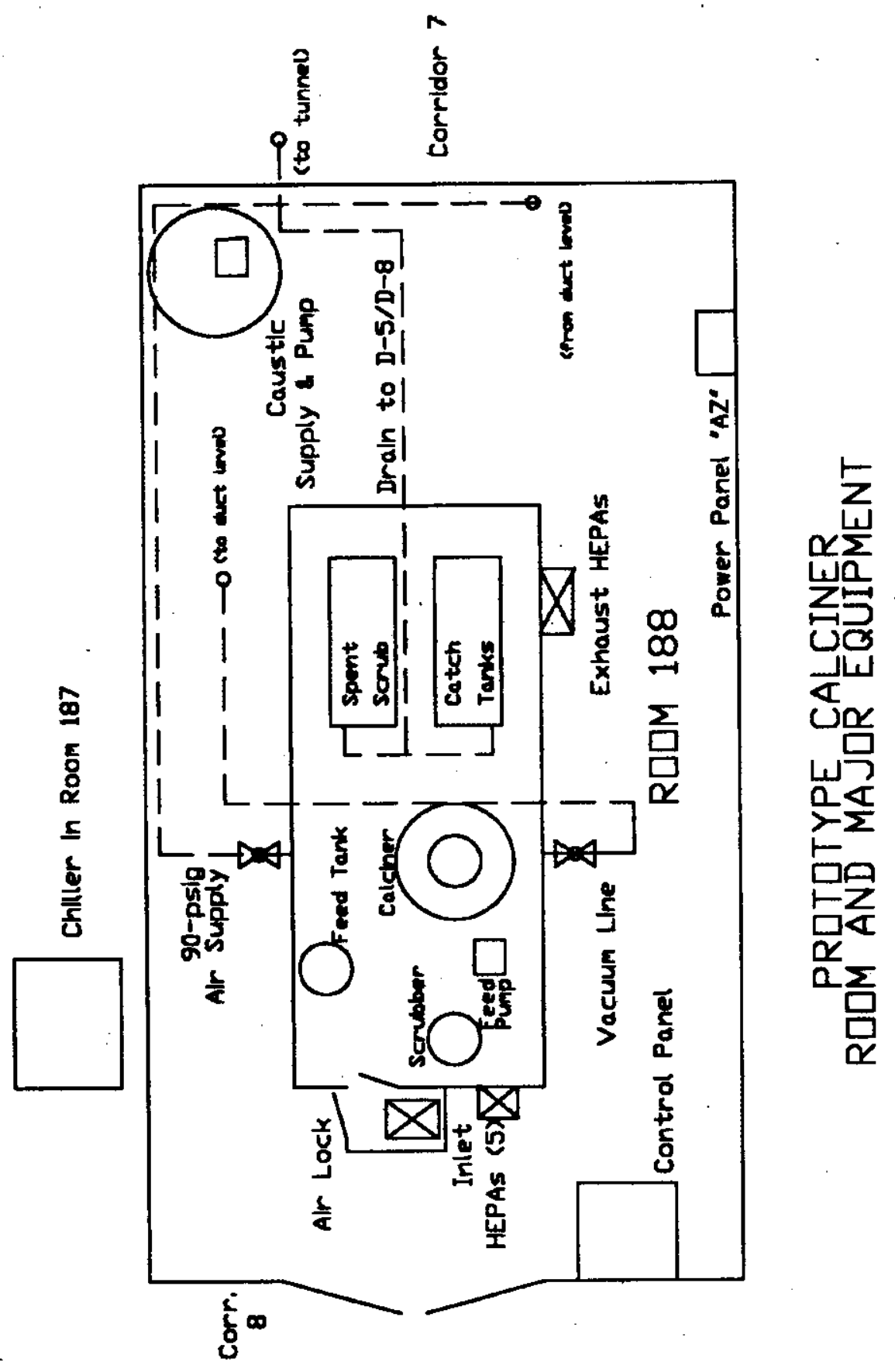




\section{Attachment A}

\section{PROTOTYPE VERTICAL DENITRATION CALCINER REVIEW TOPICS}

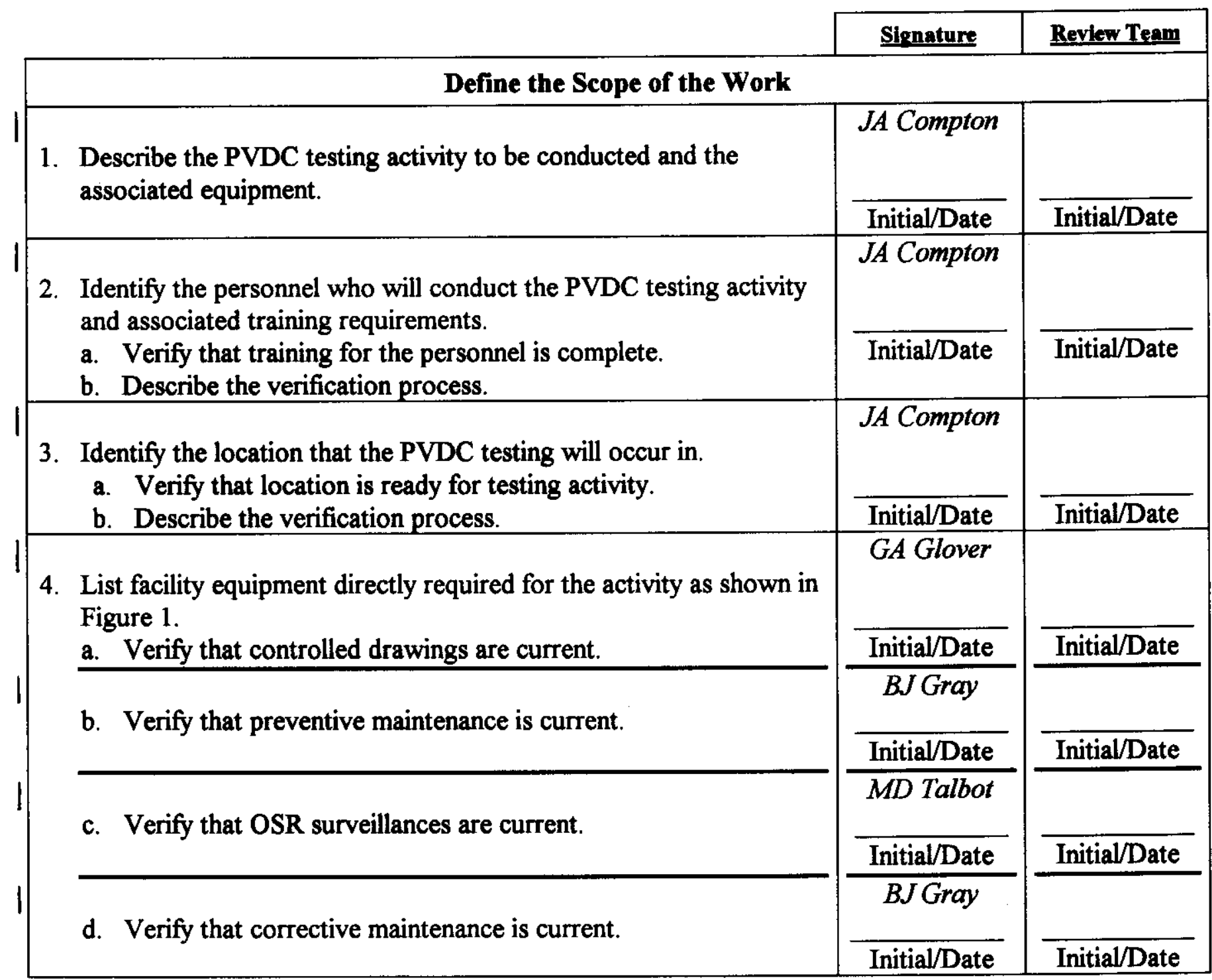


5. Identify the testing specific equipment that must be operable to support the testing.

a. Verify that modifications are completed.

b. Verify that the post modification and acceptance testing are complete.

c. Verify that controlled drawings are current and that a field walkdown has been completed to ensure proper system configuration.

d. Verify that preventive maintenance is current.

e. Verify that spare parts inventory is satisfactory.

f. Verify that consumable inventories are satisfactory.

6. List the support/dependencies required to conduct calciner testing activities.

a. Verify that support/dependencies required are ready.

b. Describe the verification process.

\section{Signature}

BJ Gray

\begin{tabular}{|c|c|c|} 
& \\
\hline ay & &
\end{tabular}

Reviaw Team

Revienten

$-$

$\frac{\overline{\text { Initial/Date }}}{\frac{\text { PE Roege }}{\text { Initial/Date }}}$

$\overline{\text { Initial/Date }}$

Initial/Date

\begin{tabular}{|c|}
\hline Initial/Date \\
JA Compton
\end{tabular}

Initial/Date

7. Describe the specific feed materials that will be tested.

8. Describe the final product from the testing activities and storage.

9. Describe the waste generated during the testing activities and disposal.

\begin{tabular}{|l|l}
\hline Initial/Date & Initial/Date \\
\hline JA Compton & \\
\hline Initial/Date & Initial/Date \\
\hline JA Compton & \\
\hline Initial/Date & Initial/Date \\
\hline
\end{tabular}




\begin{tabular}{|c|c|c|}
\hline & Signature & Review Team \\
\hline \multicolumn{3}{|l|}{ Identify the Hazards of the Work } \\
\hline \multirow{3}{*}{$\begin{array}{l}\text { Verify the PVDC testing is covered by the FSAR. } \\
\text { a. Verify that a detailed hazard review of the activity was } \\
\text { conducted, involving an engineer, technician and a safety } \\
\text { professional. }\end{array}$} & AL Ramble & \\
\hline & & \\
\hline & Initial/Date & Initial/Date \\
\hline & $\overline{J A \text { Compton }}$ & \\
\hline $\begin{array}{l}\text { b. Verify the USQ screening/evaluation is complete to ensure the } \\
\text { accident analysis adequately addresses the activity. }\end{array}$ & & Initial/Date \\
\hline \multirow[b]{2}{*}{ c. Verify the FSAR updates are completed. } & $\overline{A L ~ R a m b l e}$ & \\
\hline & & Initial/Date \\
\hline & GA Glover & \\
\hline \multirow{2}{*}{$\begin{array}{l}\text { d. Verify the FMEA updates are completed. } \\
\text { e. Verify the safety equipment list updates are completed. } \\
\text { f. Verify the SDD updates are completed. } \\
\text { g. Verify the essential drawings updates are completed. } \\
\text { h. Verify the SEL is current. }\end{array}$} & & \\
\hline & Initial/Date & Initial/Date \\
\hline \multirow[b]{2}{*}{ i. Verify the CSER updates are completed. } & $\overline{\text { AL Ramble }}$ & \\
\hline & & \\
\hline \multirow{3}{*}{$\begin{array}{l}\text { Verify that facility/site environmental permits cover this activity. } \\
\text { a. Describe the verification process. }\end{array}$} & Initial/Date & Initial/Date \\
\hline & 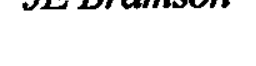 & \\
\hline & Initial/Date & Initial/Date \\
\hline \multirow{3}{*}{$\begin{array}{l}\text { 3. Verify that an AJHA has been completed for the activity. } \\
\text { a. Describe the verification process. }\end{array}$} & JA Compton & \\
\hline & & \\
\hline & Initial/Date & Initial/Date \\
\hline
\end{tabular}




\begin{tabular}{|c|c|c|}
\hline & Sirnature & Review Team \\
\hline \multicolumn{3}{|l|}{ Implement Hazard Controls } \\
\hline \multirow{3}{*}{$\begin{array}{l}\text { Review hazards listed and implement controls. } \\
\text { a. Verify that CPS and CPS postings are current and implement } \\
\text { the CSER. }\end{array}$} & AL Ramble & \\
\hline & & \\
\hline & $\overline{\text { Initial/Date }}$ & Initial/Date \\
\hline \multirow{2}{*}{ b. Verify that the RWPs are adequate. } & RS Jansons & \\
\hline & Initial/Date & Initial/Date \\
\hline \multirow[b]{2}{*}{ c. Verify OSRs have been updated and implemented. } & $J P$ King & \\
\hline & $\overline{\text { Initial/Date }}$ & Initial/Date \\
\hline \multirow{3}{*}{$\begin{array}{l}\text { 2. List engineering controls required for this activity. } \\
\text { a. Calciner heat detector } \\
\text { b. Emergency shutdown switch } \\
\text { c. Automatic Seismic Shutdown System. }\end{array}$} & JA Compton & \\
\hline & & \\
\hline & Initial/Date & Initial/Date \\
\hline \multirow{3}{*}{$\begin{array}{l}\text { 3. List tests needed to check these engineering controls. } \\
\text { a. Verify that tests have been performed. } \\
\text { b. Describe the verification process }\end{array}$} & $\overline{B J \text { Gray }}$ & \\
\hline & & \\
\hline & Initial/Date & Initial/Date \\
\hline \multirow{2}{*}{ 4. Identify the procedures required for this activity. } & JA Compton & \\
\hline & $\overline{\text { Initial/Date }}$ & Initial/Date \\
\hline \multirow{3}{*}{$\begin{array}{l}\text { 5. Verify that procedures contain controls and controls are } \\
\text { implemented. } \\
\text { a. Describe the verification process. }\end{array}$} & JA Compton & \\
\hline & & \\
\hline & $\overline{\text { Initial/Date }}$ & Initial/Date \\
\hline \multirow{3}{*}{$\begin{array}{l}\text { 6. Verify that training to implement changes in procedures and other } \\
\text { technical documents is complete. } \\
\text { a. Describe the verification process. }\end{array}$} & JA Compton & \\
\hline & & \\
\hline & $\overline{\text { Initial/Date }}$ & Initial/Date \\
\hline
\end{tabular}




\begin{tabular}{|l|rr|}
\hline $\begin{array}{l}\text { ACTIVITY BASED STARTUP PLAN FOR THE } \\
\text { PROTOTYPE VERTICAL DENITRATION CALCINER }\end{array}$ & May 26, 1999 & HNF-4522, Rev. 1 \\
Page 10 of 10
\end{tabular}

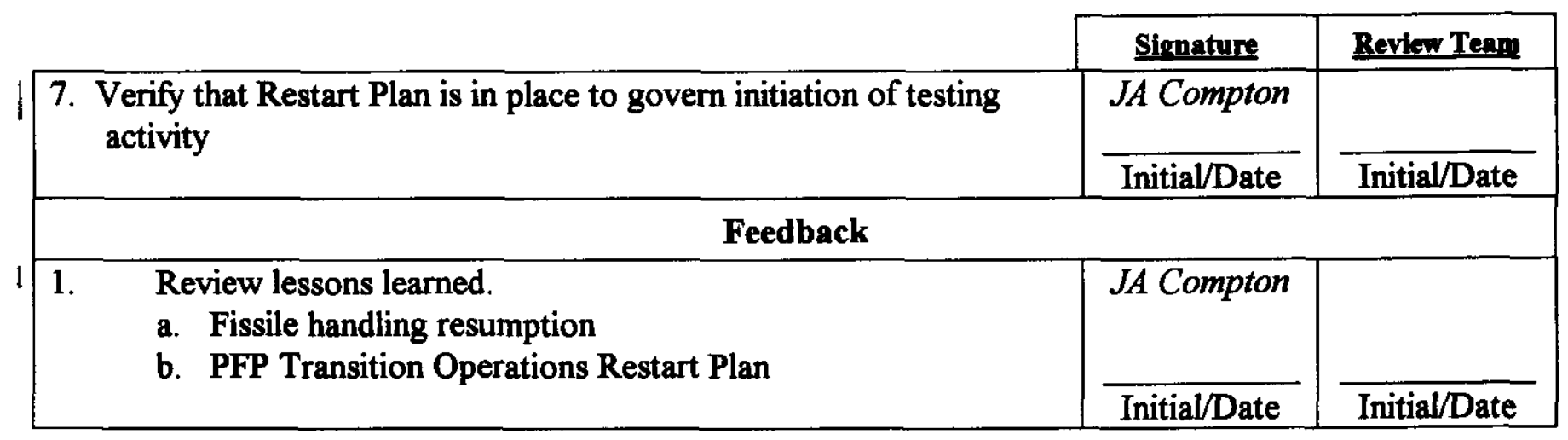

PPSL Manager review and concurrence with checklist:

C. S. Sutter, Manager

\section{Date}

Plutonium Process Support Laboratories

Concurrence with checklist and authorization to initiate Restart Plan:

F. R. Crawford, Senior Director

Date

Plutonium Finishing Plant Project

A. Clark, President and General Manager

Date

B\&W Hanford Company 


\section{DISTRIBUTION SHEET}

To

Distribution

\section{Project TitleMork Order}

HNF-4522, "Activity Based Startup Plan for the Prototype Vertical Denitration Calciner"

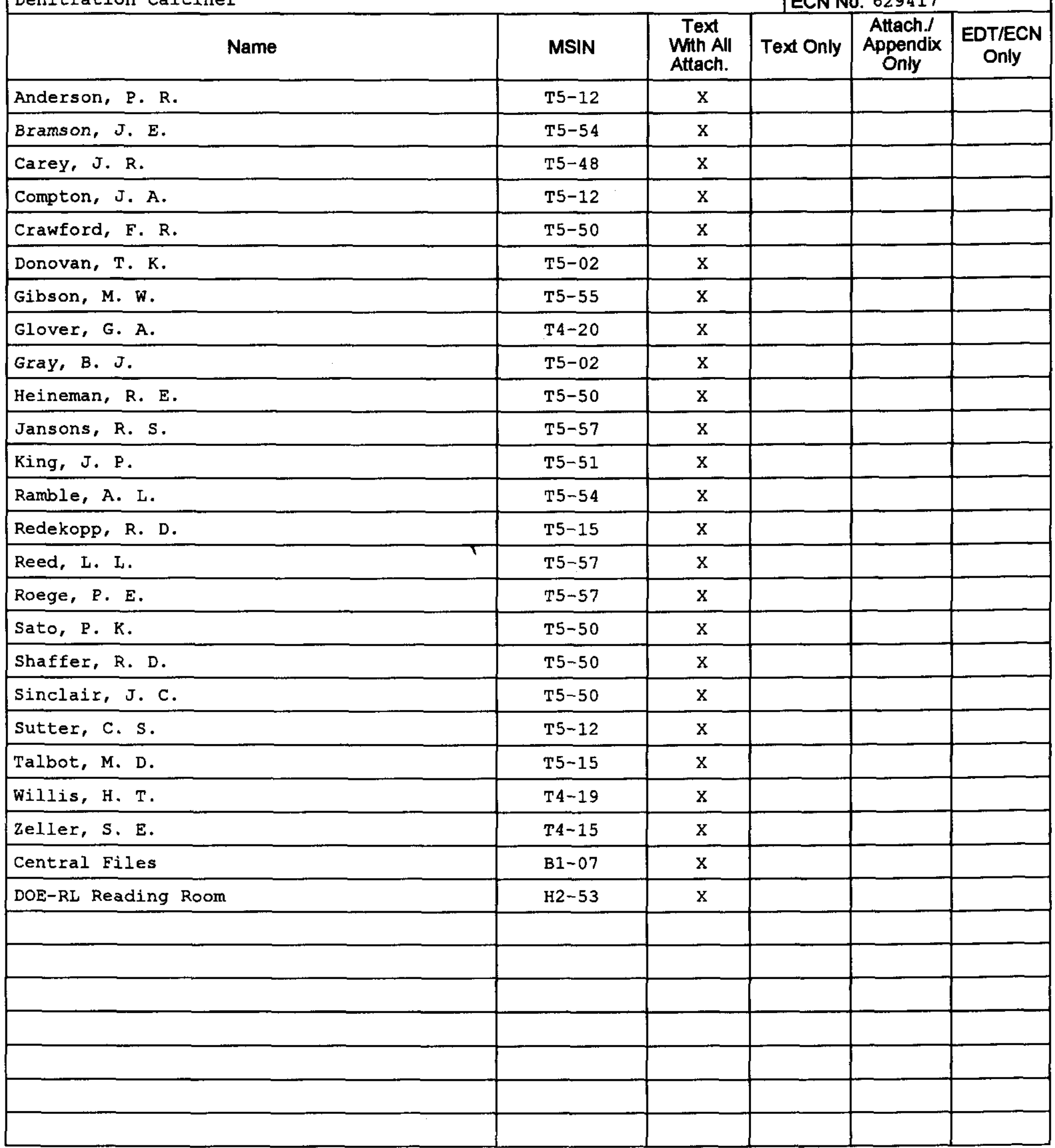

\begin{tabular}{|l} 
Page 1 of 1 \\
Date $05 / 25 / 99$
\end{tabular}

EDT No. NA

ECN No. 629417

From

c. S. Sutter 